\title{
Determinants of out-of-pocket spending on health among the poor population served by public services of health in Peru, 2010-2014*
}

\author{
Margarita Petrera Pavon ${ }^{1}$ and Eduardo Jiménez Sánchez ${ }^{2}$
}

Suggested citation (original article) Petrera Pavone M, Jiménez Sánchez E. Determinantes del gasto de bolsillo en salud de la población pobre atendida en servicios de salud púbicos en Perú, 2010-2014. Rev Panam Salud Publica. 2018;42:e20. https://doi.org/10.26633/RPSP.2018.20

ABSTRACT

Objective. To ascertain which factors affect out-of-pocket spending on health services provided by the Ministry of Health of Peru and regional governments to the population living in relative poverty between 2010 and 2014.

Materials and methods. Cross-sectional, descriptive, nationwide, econometric, year-on-year (2010-2014) study using information from household surveys. The dependent variable was out-of-pocket spending by people in relative poverty to pay for medical care at public services in health. The independent variables were affiliation with the Comprehensive Health Insurance (SIS) scheme, level of family expenditure per capita, age group 0-5 years, being a woman of childbearing age (15-49 years), being an older adult (over age 60 years), family burden (using the number of members of the household as a proxy indicator), and the level of complexity of the service provider.

Results. Only $5 \%$ of the rural population in the study were treated at higher-complexity facilities (hospitals), compared to $16 \%$ of the population in urban centers. Drugs accounted for the majority of household expenditures: 44\% among those insured via SIS and 62\% among the uninsured (2014). Out-of-pocket spending on health was positively associated with not being insured via SIS, higher level of provider complexity, level of family spending per capita, and being an older adult.

Conclusions. Comprehensive Health Insurance coverage is a relevant policy variable to reduce out-of-pocket spending in poor households. The lower out-of-pocket spending among the rural poor-an especially vulnerable group - was strongly associated with near-exclusive use of services delivered by primary health care providers. Specific policies are needed to protect older adults living in poverty. To achieve universal health coverage, Peru needs to implement more intensive financial protection policies and restructure its public service offering.

Keywords Health insurance; poverty; out-of pocket spending; universal coverage; Peru.

In October 2014, the countries of the Region of the Americas adopted a resolution aimed at advancing toward universal access to health and universal health coverage in the coming decades. One of the four strategic lines established to this end was to increase public financing and reduce out-of-pocket

\footnotetext{
* Official English translation from the original Spanish manuscript made by the Pan American Health Organization. In case of discrepancy, the original version (Spanish) shall prevail.
}

household spending (1). In Peru, the National Agreement initiative is a space for dialogue to reach consensus among the Government, political parties, and civil society organizations on State policies to put the country on a sustainable growth path within the framework of social equity and democracy building

\footnotetext{
Universidad Peruana de Ciencias Aplicadas, Facultad de Posgrado, Pontificia Universidad Peruana Católica del Perú, Lima, Perú. $\triangle$ Margarita Petrera Pavon: mpetrerap@gmail.com

2 Universidad Nacional Mayor de San Marcos, Lima, Perú.
} 
(2). In June 2015, one of the key objectives of the Health System Reform for 2021 was to strengthen the country's comprehensive health insurance program-known as SIS, its Spanish acronym - as "the grand instrument for universalizing access to comprehensive health care and treatment" (3).

Public health insurance was introduced in Peru in 1998 with Free School Insurance and, since 1999, has benefited children in the nation's schools through Maternal and Child Insurance in some locations. The two types of insurance were ultimately merged to become what was then called Public Health Insurance (2001), renamed as SIS in 2002, with the main objective of "building a public insurance system that finances and promotes equitable access to health services for the uninsured population, giving priority to vulnerable groups living in poverty and extreme poverty" (4).

With the Universal Health Insurance Strategy, established in the Law of the same name in 2009 (5) and its regulations in 2010 (6), SIS became the insurer of the subsidized system for the population living in poverty, regardless of age group and fully financed with public funds. The public health facilities of the Ministry of Health (MINSA) and regional governments are the main providers of the health services sought by SIS beneficiaries; thus, enrollment in SIS would be expected to significantly reduce out-of-pocket, or direct, health expenditure. The World Health Organization (WHO) defines this expenditure as fees, charges or any type of payment made for medical consultations, diagnostic procedures, or treatment, with or without a formal, informal, or traditional medical prescription, in addition to copayments and deductibles, as seen in some types of health insurance (7).

There is empirical evidence that SIS had a protective effect on access to health services in 2010, when it was shown that the probability of a beneficiary having access to health services was three times higher than that of a nonbeneficiary and that, while not all SIS beneficiaries who sought care from MINSA's national network received it totally free of charge, people in relative poverty who were SIS beneficiaries reported lower out-of-pocket health spending than those who were not. (8). A similar, though perhaps smaller (9), effect was reported in the National Health Accounts between 2004 and 2012 (9, 10).

In Peru, some $61 \%$ of out-of-pocket expenditure for medical care from a public health service provider (MINSA and regional governments) goes to nearby private facilities (pharmacies, diagnostic centers, and laboratories) (9).

According to WHO, out-of-pocket health expenditure is regressive, exclusive, does not spread the costs across groups of people, and does not anticipate diseases or accidents, jeopardizing primarily the health of poor people who cannot pay for needed services (7). Average spending by households in Latin America accounts for $45 \%$ of total health expenditure, a higher percentage than in the European countries and members of the Organization for Economic Cooperation and Development (OECD), not only making it one of the principal sources of inequity but keeping countries from advancing toward universal health coverage (11). Although out-of-pocket spending in Peru was low $(37 \%)$, it was still the main source of health services financing in 2012 (9). Global studies show that out-of-pocket spending depends on the ability to pay, demographic aspects, the development of diseases, the types of health services provided, and technological change $(12,13)$. Seven countries (Argentina, Brazil, Chile, Colombia, Ecuador, Mexico, and Uruguay) have three characteristics in common that increase the level of out-ofpocket expenditure: being a head of household over the age of 65 , the presence of older persons in the household, and hospitalization (14). In studies in Mexico, the following were selected as explanatory variables of out-of-pocket expenditure: enrollment in the People's Health Insurance (Seguro Popular de Salud), per capita spending, and belonging to specific age groups (ages $0-5$, woman of reproductive age, older person) $(15,16)$. Similar findings were reported in Chile, although with a diminishing impact on these age groups $(17,18)$.

The objective of this study, focused on the population in relative poverty, was to ascertain what factors affected out-ofpocket expenditure on health services provided by MINSA and regional governments between 2010 and 2014.

\section{MATERIALS AND METHODS}

A descriptive cross-sectional econometric study was conducted nationwide with annual cut-off points between 2010 and 2014. Secondary information from the databases of the National Household Survey (ENAHO) for this period was used. This survey, which has been conducted by the National Statistics and Informatics Institute (INEI) since 1995, is in the public domain and targets households with the object of exploring the population's standard of living (19). People living in private dwellings in urban and rural areas of the country were surveyed. The informants were head of household, spouse, income recipients, and people aged 12 and older. The method employed was direct interviews using mobile devices for data collection (PDA). The field staff consisted of departmental coordinators, supervisors, and interviewers. An independent, probabilistic, multi-stage stratified area sample was used in the study area. The confidence level of the sample estimates was $95 \%$.

The target population of this study was a sample consisting of people living in relative monetary poverty (quintiles 1 and 2 of household expenditure per capita) and who, having stated that they had a disease or had had an accident that affected their health, used the health services of public MINSA or regional government providers and had made some out-of-pocket payment for that care. The selected subsample consisted of 2149 (2010) and 2807 people (2014).

Expenditure per capita was calculated from INEI estimates of total household expenditure (food, caregiving, education, health, housing, etc.) divided by the number of household members. Household expenditure per capita was used to divide the population into quintiles of household expenditure per capita, which, according to the literature (17), is a good measure of economic well-being. The population in relative monetary poverty is defined as the population in the first two quintiles of that distribution.

The inclusion criteria were: a) people in quintiles 1 and 2 of household expenditure per capita, b) those stating that they had a disease or had had an accident that affected their health and who had used the health services of public MINSA or regional government providers in the past four weeks or had been hospitalized in the past 12 months, and (c) those stating that they had made some out-of-pocket payment for that care, excluding people who had received free services (payment $=$ $0)$. Information about SIS enrollment was obtained from the ENAHO. 
The exclusion criteria were: a) people in quintiles 3,4 , and 5 of household expenditure per capita, b) those not stating that they had a disease or had had an accident and who had health insurance other than SIS, d) those who, having stated that they had a disease or had had an accident, did not use the health services of public MINSA or regional government providers in the past four weeks or had not been hospitalized in the past 12 months, e) those who, having used the health services of public MINSA or regional government providers in the past four weeks or having been hospitalized in the past 12 months, had had no out-of-pocket expenditures for health services.

The dependent variable in the study was out-of-pocket expenditure or direct payments by people in relative poverty to cover the care received from public MINSA and regional government providers to treat a health problem. Operationally, the type of expenditure (greater than 0 ) for a member of the household for the following was identified: drugs, medical supplies, glasses, orthopedic and therapeutic devices, consultations with a physician, surgical interventions, other professional fees, dental care, laboratory tests and services, x-rays and imaging, hospitalization services, mobile emergency services, and insurance copayments.

This variable does not have a normal distribution or absolute or logarithmic value. However, there is no need to relax the assumption of normality if the objective is simply to make the estimate, because the extension of the central limit theorem is taken into account and, thus, Student's t test and Snedecor's F test are still valid asymptotically-that is, in large samples such as in this study $(21,22)$.

The independent variables were: SIS enrollment, the level of household expenditure per capita, the age group (child aged 0-5, woman of reproductive age (15-49), older person (60), a dependent relative (whose proxy indicator was the number of household members), and the level of complexity of the service provider where the care was received (whose proxy indicator was a dichotomous variable: hospital = higher complexity and health center/health post = lower complexity).

Since $95 \%$ of the rural population was seen in lower-complexity facilities, the urban/rural residence of the patient could not be used as a variable in the regression, due to the potential for collinearity between the level of complexity and the area. Since the rural population accounted for $61.5 \%$ of the total sample population, the investigators opted to focus on the level of complexity accessed (Table 1 ). A robust estimate was made-that is, the true variance and covariance matrix was calculated to eliminate the possibility of nonspherical disturbances $(21,22)$.

To estimate the associations between out-of-pocket expenditure and the selected independent variables, a multivariate linear regression model was constructed. Individual regressions were performed for each year of the period 2010-2014. In the models, the terms of interaction between SIS enrollment and the other independent variables were introduced and subsequently excluded because they were not statistically significant.

The specification of the regression is logarithmic for the continuous variables, making it possible to interpret its parameters as elasticity-that is, the extent to which a percentage variation in the independent variable is associated with a percentage variation in the dependent variable. In the case of the dichotomous variables, the parameters should be interpreted as semi-elasticity-that is, the presence of the characteristics (being an SIS beneficiary, for example) is associated with the
TABLE 1. Distribution of the study population by area, Peru, 2014

\begin{tabular}{lccc}
\multicolumn{2}{c}{$\begin{array}{c}\text { Annual household health expenditure } \\
\text { per capita (soles) }\end{array}$} & $\begin{array}{c}\text { People seen in } \\
\text { primary care }(\%)\end{array}$ & $\begin{array}{c}\text { Population studied } \\
(\%)\end{array}$ \\
Urban & 332 & 84.4 & 38.5 \\
Rural & 247 & 95.3 & 61.5 \\
National total & 287 & 91.1 & 100.0 \\
\hline
\end{tabular}

Source: Instituto Nacional de Estadística e Informática, base de datos, Módulos Sumaria y Salud, ENAHO 2010-2014.

TABLE 2. Averages of the independent variables of the study sample by year, Peru, 2010-2014

\begin{tabular}{cccccccc} 
Year & $\begin{array}{c}\text { Annual } \\
\text { household } \\
\text { expenditure } \\
\text { per capita }\end{array}$ & $\begin{array}{c}\text { Children } \\
(0-5 \\
\text { years })\end{array}$ & $\begin{array}{c}\text { Women of } \\
\text { reproductive } \\
\text { age }\end{array}$ & $\begin{array}{c}\text { Older } \\
\text { persons }\end{array}$ & $\begin{array}{c}\text { Enrolled } \\
\text { in SIS }\end{array}$ & $\begin{array}{c}\text { Household } \\
\text { members }\end{array}$ & $\begin{array}{c}\text { People } \\
\text { seen } \\
\text { in a } \\
\text { hospital }\end{array}$ \\
2010 & 2331 & 0.18 & 0.27 & 0.12 & 0.96 & 5.51 & 0.11 \\
2011 & 2533 & 0.17 & 0.28 & 0.15 & 0.95 & 5.36 & 0.12 \\
2012 & 2717 & 0.12 & 0.28 & 0.17 & 0.94 & 5.23 & 0.14 \\
2013 & 2938 & 0.12 & 0.28 & 0.19 & 0.94 & 5.18 & 0.12 \\
2014 & 3096 & 0.12 & 0.27 & 0.21 & 0.94 & 4.98 & 0.12 \\
\hline
\end{tabular}

Source: Instituto Nacional de Estadística e Informática, base de datos, Módulos Sumaria y Salud, ENAHO 2010-2014. SIS = Seguro Integral de Salud.

percentage change in health expenditure and is equal to the estimated parameter multiplied by 100 . The analyses were performed using STATA 13 software.

Because secondary information from the ENAHO databases, which are public and anonymous, was used, people's identity cannot be revealed.

\section{RESULTS}

Although the population in monetary poverty during the period studied generally accessed the first level of care $(91.1 \%)$, in 2014 the rural population did so to a greater extent $(62 \%$, in contrast to the urban population's 38.5\%) and had fewer consultations in higher-complexity facilities (only 5\%, in contrast to the urban population's 16\%) (Table 1).

The averages of the sample's independent variables during the period $2010-2014$ show a decrease from $18 \%$ to $12 \%$ in the under-5 population, an increase from $12 \%$ to $21 \%$ in older persons, and a decrease in the number of household members from 5.5 to 5.0, a phenomenon compatible with the demographic transition. A high percentage of the sample population was enrolled in SIS, which may suggest that the population in relative in monetary poverty preferentially seeks care in public facilities, even when some payment is required (Table 2).

In general, during the period 2010-2014, the trend in the outof-pocket expenditure of people in relative monetary poverty, in constant soles, was slightly upward, but less so in SIS beneficiaries than nonbeneficiaries (Table 3). Expressed in purchasing power parity (PPP) dollars (23) and using the 2014 exchange rate, in 2010 this expenditure was USPPP $\$ 161$ for beneficiaries and USPPP\$ 180 for nonbeneficiaries. In 2014, these figures were USPPP\$ 182 and USPPP\$ 209, respectively.

Drugs were the principal explanatory factor for the out-ofpocket health expenditure of the population in relative monetary poverty. In 2014, of the total out-of-pocket expenditure for care 
TABLE 3. Out-of-pocket health expenditure1 of the population in relative monetary poverty by enrollment, Peru, 2010-2014

\begin{tabular}{|c|c|c|c|c|c|c|c|c|c|c|c|}
\hline Enrollment & \multicolumn{5}{|c|}{ Year } & \multicolumn{4}{|c|}{ Year } & \multicolumn{2}{|c|}{$\begin{array}{l}\text { Coefficient of } \\
\text { variation }\end{array}$} \\
\hline SIS beneficiary & 252 & 291 & 312 & 297 & 285 & 231 & 273 & 257 & 312 & 0.04 & 0.05 \\
\hline
\end{tabular}

Source: Instituto Nacional de Estadística e Informática, base de datos, Módulos Sumaria y Salud, ENAHO 2010-2014.

1 Deflated by the Consumer Price Index for Medical Care. Cl95\% = confidence Interval of $95 \%$. SIS = Comprehensive Health Insurance.

TABLE 4. Percentage composition of the type of personal out-of-pocket health expenditure of the population in relative monetary poverty by year and enrollment, Peru, 2010-2014

\begin{tabular}{|c|c|c|c|c|c|c|c|c|c|c|c|c|}
\hline Enrollment & $\begin{array}{c}\text { Type of } \\
\text { expenditure }\end{array}$ & \multicolumn{5}{|c|}{ Year } & \multicolumn{2}{|c|}{2010 (Cl95\%) } & \multicolumn{2}{|c|}{2014 (Cl95\%) } & \multicolumn{2}{|c|}{$\begin{array}{l}\text { Coefficient of } \\
\text { variation }\end{array}$} \\
\hline \multirow[t]{3}{*}{ SIS beneficiary } & Consultation & 6.3 & 6.7 & 6.9 & 5.8 & 4.4 & 5.3 & 7.3 & 3.6 & 5.2 & 0.16 & 0.18 \\
\hline & $\begin{array}{l}\text { Hospitalization/ } \\
\text { surgery }\end{array}$ & 4.4 & 4.4 & 4.9 & 3.9 & 3.6 & 3.4 & 5.4 & 2.9 & 4.4 & 0.23 & 0.20 \\
\hline & Consultation & 23.3 & 22.2 & 24.5 & 23.2 & 22.5 & 21.1 & 25.5 & 20.3 & 24.7 & 0.10 & 0.10 \\
\hline \multirow{3}{*}{$\begin{array}{l}\text { SIS } \\
\text { nonbeneficiary }\end{array}$} & Drugs & 62.5 & 63.0 & 59.3 & 60.7 & 62.0 & 59.7 & 65.2 & 59.2 & 64.8 & 0.04 & 0.04 \\
\hline & $\begin{array}{l}\text { Hospitalization/ } \\
\text { surgery }\end{array}$ & 2.0 & 2.4 & 2.8 & 1.1 & 1.7 & 0.9 & 3.2 & 0.6 & 2.8 & 0.56 & 0.66 \\
\hline & $\begin{array}{c}\text { Other } \\
\text { expenditures }{ }^{1}\end{array}$ & 12.2 & 12.5 & 13.4 & 15.1 & 13.8 & & & & & & \\
\hline
\end{tabular}

Source: Instituto Nacional de Estadística e Informática, base de datos, Módulos Sumaria y Salud, ENAHO 2010-2014. CI = confidence Interval.

SIS = Comprehensive Health Insurance.

${ }^{1}$ Other expenditures include laboratory analyses, diagnoses and other tests, delivery care, dental and related services, ophthalmological services, purchase of glasses, prenatal check-ups, vaccines, well-children monitoring, contraceptives, thermometers, and other supplies.

received from MINSA and regional government providers, SIS beneficiaries spent $44 \%$ on drugs, and nonbeneficiaries, $62 \%$. Nevertheless, this type of expenditure fell among SIS beneficiaries from $56.5 \%$ (2010) to $44.0 \%$ (2014) (Table 4 ).

The results of the logarithmic multivariate linear regression of the out-of-pocket health expenditure of the population in relative poverty on MINSA and regional government care for each year of the period 2010-2014 show that the majority of the associations between the model's explanatory variables and out-of-pocket expenditure are statistically significant (Table 5). Thus, SIS enrollment is associated with a $28.4 \%-60.1 \%$ reduction in this expenditure. Receiving care in a hospital rather than a health post or health center and a higher household income increased this expenditure. Receiving care in a hospital increased out-of-pocket health expenditure by $91.4 \%-113.5 \%$ due to the higher complexity of the health services provided, resulting in higher expenditures; this is found more often among urban dwellers than rural dwellers. Each 1\% increase in an individual's total spending (i.e., being relatively less poor) is associated with a $0.6 \%-1.1 \%$ increase in out-of-pocket health expenditure.

Being under 5 years of age increases out-of-pocket expenditure, although this association was statistically significant only in 2010 (being in this age group is associated with a $25.3 \%$ increase in out-of-pocket expenditure). In women of reproductive age, the association was inverse in all years, although it was statistically significant only in 2012 and 2014, with reductions in out-of-pocket expenditure of $13.4 \%$ and $20.7 \%$, respectively. Being an older person was associated with increases in out-ofpocket expenditure, although the associations were statistically significant only in 2013 and 2014 (20.7 and 13.4\%, respectively). A one-member increase in the size of a household was significantly associated with an increase in out-of-pocket expenditure in all years ranging from 3.0\% (2010) to 6.6\% (2014).

\section{DISCUSSION}

The rural population makes less use of higher-complexity health services than the urban population does, indicating that, in Peru, rurality is a determinant of social exclusion. Furthermore, the observation that $61 \%$ of the out-of-pocket expenditure of people who see a public provider ends up being complemented with expenditures in the private system is linked with the observation of the Ombudsman's Office pointing to a dearth of services, inputs, and diagnostic tests in public facilities, including those covered under the Essential Health Services Plan (EAP), which are supposed to be compulsory (24). In 2016, the executed financing of SIS was only $13 \%$ of MINSA and regional government expenditure (25), an amount entirely insufficient to guarantee effective coverage of the 
TABLE 5. Regression model of the personal out-of-pocket health expenditure of the population in relative monetary poverty, Peru, 2010-2014

\begin{tabular}{|c|c|c|c|c|c|}
\hline Variables & 2010 & 2011 & 2012 & 2013 & 2014 \\
\hline $\begin{array}{l}\text { Household } \\
\text { expenditure } \\
\text { per capita in } \\
\text { logarithms }\end{array}$ & $\begin{array}{l}0.647^{\star * *} \\
(-0.0879)\end{array}$ & $\begin{array}{l}0.746^{\star \star \star} \\
(-0.081)\end{array}$ & $\begin{array}{l}0.732^{\star \star \star} \\
(-0.0852)\end{array}$ & $\begin{array}{l}0.822^{\star * *} \\
(-0.0789)\end{array}$ & $\begin{array}{l}1.068^{* \star *} \\
(-0.0824)\end{array}$ \\
\hline $\begin{array}{l}\text { Being a child } \\
\text { (aged 0-5) }\end{array}$ & $\begin{array}{l}0.253^{\star \star \star} \\
(-0.0781)\end{array}$ & $\begin{array}{l}0.0679 \\
(-0.078)\end{array}$ & $\begin{array}{l}0.126 \\
(-0.0885)\end{array}$ & $\begin{array}{l}0.133 \\
(-0.0821)\end{array}$ & $\begin{array}{l}0.109 \\
(-0.0831)\end{array}$ \\
\hline $\begin{array}{l}\text { Being a } \\
\text { woman of } \\
\text { reproductive } \\
\text { age }\end{array}$ & $\begin{array}{l}-0.0718 \\
(-0.0791)\end{array}$ & $\begin{array}{l}-0.00511 \\
(-0.0731)\end{array}$ & $\begin{array}{l}-0.134^{*} \\
(-0.0753)\end{array}$ & $\begin{array}{l}-0.0559 \\
(-0.068)\end{array}$ & $\begin{array}{l}-0.207^{\star \star *} \\
(-0.0691)\end{array}$ \\
\hline $\begin{array}{l}\text { Being an } \\
\text { older person }\end{array}$ & $\begin{array}{l}0.12 \\
(-0.101)\end{array}$ & $\begin{array}{l}0.11 \\
(-0.09)\end{array}$ & $\begin{array}{l}0.153 \\
(-0.0945)\end{array}$ & $\begin{array}{l}0.207^{\star * *} \\
(-0.0795)\end{array}$ & $\begin{array}{l}0.134^{\star} \\
(-0.0795)\end{array}$ \\
\hline $\begin{array}{l}\text { Enrollment } \\
\text { in SIS }\end{array}$ & $\begin{array}{l}-0.284^{\star \star} \\
(-0.123)\end{array}$ & $\begin{array}{l}-0.372^{\star \star \star} \\
(-0.111)\end{array}$ & $\begin{array}{l}-0.437^{\star \star \star} \\
(-0.103)\end{array}$ & $\begin{array}{l}-0.601^{* \star *} \\
(-0.0823)\end{array}$ & $\begin{array}{l}-0.374^{\star \star *} \\
(-0.0937)\end{array}$ \\
\hline $\begin{array}{l}\text { Number of } \\
\text { household } \\
\text { members }\end{array}$ & $\begin{array}{l}0.0302^{\star *} \\
(-0.0141)\end{array}$ & $\begin{array}{l}0.0640 * * * \\
(-0.0132)\end{array}$ & $\begin{array}{l}0.0361^{\star *} \\
(-0.0149)\end{array}$ & $\begin{array}{l}0.0409^{\star \star *} \\
(-0.013)\end{array}$ & $\begin{array}{l}0.0655^{\star * \star} \\
(-0.014)\end{array}$ \\
\hline $\begin{array}{l}\text { Receiving } \\
\text { care in a } \\
\text { hospital }\end{array}$ & $\begin{array}{l}1.075^{\star \star \star} \\
(-0.101)\end{array}$ & $\begin{array}{l}1.055^{\star \star \star} \\
(-0.0894\end{array}$ & $\begin{array}{l}1.135^{\star \star \star} \\
(-0.0907)\end{array}$ & $\begin{array}{l}0.914^{\star * *} \\
(-0.0895)\end{array}$ & $\begin{array}{l}1.012^{* * *} \\
(-0.0846)\end{array}$ \\
\hline Constant & $\begin{array}{l}-0.501 \\
(-0.713)\end{array}$ & $\begin{array}{l}-1.358^{\star \star} \\
(-0.675)\end{array}$ & $\begin{array}{l}-1.099 \\
(-0.706)\end{array}$ & $\begin{array}{l}-1.775^{\star \star \star} \\
(-0.662)\end{array}$ & $\begin{array}{l}-4.043^{\star \star \star} \\
(-0.693)\end{array}$ \\
\hline Sample size & 2.149 & 2.573 & 2.185 & 2.931 & 2.807 \\
\hline R-square & 0.099 & 0.108 & 0.12 & 0.099 & 0.134 \\
\hline
\end{tabular}

Source: Instituto Nacional de Estadística e Informática, base de datos, Módulos Sumaria y Salud, ENAHO 2010-2014. Robust estimates of standard errors appear in parentheses.

${ }^{* * *} P<0.01,{ }^{* \star} P<0.05, P<0.1$

services financed by SIS. Although at its start in 2002, thanks to the existence of unutilized capacity, SIS financed only current expenditure on drugs and inputs, with the exhaustion of that capacity, its limited financing also came to be used to cover the cost of human resources and infrastructure, exacerbating the financial situation and creating an urgent need to discuss SIS's financing role.

Although the benefits of SIS enrollment reduced the weight of drugs in out-of-pocket spending $(44.0 \%$ among beneficiaries versus $62.0 \%$ among nonbeneficiaries), this benefit is inadequate. Similar percentages have been reported in other countries-for example, in Mexico (41.3\%), with the People's Health Insurance in $2008(15,16)$, and in Chile, where it was $40 \%$ among the poorest group (A) of FONASA beneficiaries and $73.8 \%$ among nonbeneficiaries in 2007 (18). In Chile, insurance may have largely been covering low-cost drugs and, although a high percentage of enrollees benefitted, the effect on financial coverage was limited (18).

Although SIS enrollment is associated with a decline in out-of-pocket expenditure, the regression model shows that it increases with the level of complexity of the facility used, creating an access barrier for rural people due to their lower spending power. In older persons, a population group that may be defenseless and living in poverty, the risk of exclusion increases markedly. The results obtained are compatible with those described on a worldwide scale for the general population $(12,13)$. They are also compatible with those of the studies conducted in Argentina, Brazil, Chile, Colombia, Ecuador, Mexico and Uruguay, in which it was observed that being a head of household over the age of 65 and the presence of older persons increase out-of-pocket expenditure. Furthermore, the presence of children under 5 in the household increases out-of-pocket expenditure in Chile and Mexico and decreases it in Argentina, which has preferential maternal and child plans (14). Furthermore, in the Mexico studies, the explanatory variables of out-of-pocket expenditure were enrollment in the People's Health Insurance, the level of expenditure per capita, and belonging to specific age groups (0-5 years, woman of reproductive age, and older person) (16), a finding similar to that of the Chile study, although in that country, the impact of the expenditure on these age groups was declining (17).

The positive effect on the expenditure for children under 5 observed in 2010, which disappeared in subsequent years, may have been due to the steady improvement in programs targeting this age group. The slightly positive effect of household size (dependents) on out-of-pocket expenditure could suggest that as the number of household members increases, so does the probability of falling ill.

The limitations of this study stem from the limitations of the ENAHO: 1) those caused by the size of the sample and by nonresponse in the "expenditure in health facilities" category; 2) as in every household survey, a recall bias may be been introduced, and, to control it, the survey limited the time to the past three weeks for consultations and the past year for hospitalizations; 3) since visits to private homes and occupants was the basis for including households, the survey excluded members of the armed forces living in barracks, camps, on ships, and in other places. It also excluded the residents of group housing (hotels, hospitals, nursing homes, convents, prisons, etc.). The fact that other studies of health expenditure based on surveys conducted in consultation with public facilities are not available makes this the principal strength of this investigation.

The conclusion reached is that insufficient SIS financing is one of the causes of its beneficiaries' out-of-pocket expenditure. This calls for discussions at the highest level on the specific role of SIS as a financing fund and for launching a major financial reform, not only to increase financing but to improve its organization and transparency. Furthermore, the supply of public services is limited, requiring action to meet the challenges involved in increasing the supply of human resources, introducing the necessary technologies and infrastructure and, especially, managing it all to offer the population the services it needs. Older persons are an especially vulnerable group that will grow as the demographic transition progresses.

Acknowledgment. The authors would like to thank economist Lorena Prieto Toledo for her comments.

Financing. No financing was received for this study.

Conflicts of interest. The authors declare that they have no conflicts of interest.

Disclamer. The opinions expressed in this manuscript are the authors' responsibility and do not necessarily reflect the opinions or policy of the RPSP/PAJPH and/or PAHO. 


\section{REFERENCES}

1. Pan American Health Organization. Strategy for Universal Access to Health and Universal Health Coverage. Washington, DC: OPS; 2014. Available from: https://www.paho.org/hq/dmdocu ments/2014/CD53-5-e.pdf. Cited 2017 December 30.

2. Secretaría Ejecutiva del Acuerdo Nacional. Acuerdo Nacional. Lima: Secretaría Ejecutiva del Acuerdo Nacional; 2015. Available from: http:/ / acuerdonacio-nal.pe/politicas-de-estado-del-acuerdo-na cional/definicion/. Cited 2017 October 15. Cited 2017 December 30.

3. Secretaría Ejecutiva del Acuerdo Nacional. Acuerdo Nacional. Los objetivos de la Reforma de Salud 2015. Lima: Secretaría Ejecutiva del Acuerdo Nacional; 2015. Available from: http://acuerdona cio-nalperu.tripod.com. Cited 2017 December 30.

4. Ministerio de Salud. Ley 27657/2002 de 28 de enero. Lima: Diario Oficial El Peruano; 2002;216517. Available from: http:// www.minsa.gob.pe/dgsp/archivo/LeyMarco.pdf. Cited 2017 December 30.

5. Ley 29344. Ley Marco de Aseguramiento Universal en Salud. Lima: Diario Oficial El Peruano; 2009:394077. Available from: http:// diariooficial.elperuano.pe/ Normas. Cited 2017 December 30.

6. Reglamento de la Ley Marco de Aseguramiento Universal en Salud. Decreto Supremo 0082010-SA/2010 de 2 de abril. Lima: Diario Oficial El Peruano; 2010:416633. Available from: http://www.minsa .gob.pe/dgsp/archivo/LeyMarco.pdf. Cited 2017 December 30.

7. World Health Organization. Health Systems Financing. The path to universal coverage. Geneva: WHO; 2010 Available from: https://apps.who.int/iris/bitstream/handle /10665/44371/9789241564021_eng.pdf?sequence=1. Cited 2017 December 30.

8. Petrera M. Aseguramiento en salud en el Perú ¿Existe un efecto inclusivo del Seguro Público en Salud? Berlín: Editorial Académica Española; 2012.

9. Ministerio de Salud. Cuentas Nacionales en Salud. Perú: 1995-2012. Lima: MINSA; 2015. Available from: http://bvs.minsa.gob.pe:81 /local/MINSA/3248.pdf. Cited 2017 December 30.

10. Petrera M. Reflexiones para la política sectorial de salud en Perú a partir de las Cuentas Nacionales de Salud. Economía (PUCP). 2016;39(78):35-65. Available from: http://revistas.pucp.edu .pe/index.php/economia/article/view/16513. Cited 2017 December 30.

11. Titelman D, Cetrángolo O, Acosta OL. Universal health coverage in Latin American Countries: how to improve solidarity-based schemes. The Lancet https://www.thelancet.com/journals /lancet/article/PIIS0140-6736(14)61780-3/fulltext.

12. Saksena P, Holly A. The determinants of health expenditure. A CountryLevel Panel Data Analysis. Geneva: WHO; 2011. (Working Paper.) Available from: who.int/health_financing/documents /report_en_11_deter-he.pdf Cited 2017 December 30.

13. Xu K. Distribution of health payments and catastrophic expenditures. Geneva: World Health Organization; 2005. (Discussion paper No. 2.) Available from: https://apps.who.int/iris/bitstream /handle/10665/69030/EIP_HSF_DP_05.2.pdf?sequence=1\&isAl lowed $=\mathrm{y}$. Cited 2017 December 30.

14. Perticara M. Incidencia de los gastos de bolsillo en salud en siete países latinoamericanos. Santiago de Chile: CEPAL-PNUD; 2008.
(Serie Políticas Sociales 141.) Available from: http://www.cepal .org/es/publicaciones/6146-incidencia-gastos-bolsillo-salud-sie te-paises-latinoamerica-nos. Cited 2017 December 30.

15. Gakidou E, Lozano R, González-Pier E, Abbot-Klanffter J, Barofky JT, BrysonKahn C, et al. Evaluación del impacto de la Reforma Mexicana de salud 2001-2006: Un informe inicial. Salud Publica Mex. 2007;49(Supl 1):S88-S109. Available from: http://www.scielo.org $. \mathrm{mx} /$ scielo.php? s-cript $=$ sci_arttext\&pid $=$ S0036-36342007000 700011. Cited 2017 December 30.

16. Knaul FM, González-Pier E, Gómez-Dantés O, García-Junco D, Arreola-Ornelas H, Barraza-Llórens M, et al. Hacia la cobertura universal en salud: protección social para todos en México. Salud Publica Mex. 2013; 55(2):207-35. Available from: http://www.scie losp.org/pdf/spm/v55n2/v55n2a13.pdf. Cited 2017 December 30.

17. Cid C, Prieto L. El gasto de bolsillo en salud: El caso de Chile 1997 y 2007. Rev Panam Salud Publica. 2012;31(4):310-16. Available from: http://www.scielosp.org/pdf/rpsp/v31n4/a07v31n4.pdf. Cited 2017 December 30.

18. Castillo-Laborde C, Villalobos P. Caracterización del gasto de bolsillo en salud en Chile: Una mirada a dos sistemas de protección. Rev Med Chile. 2013; 141(11):1456-63. Available from: http:/ /dx.doi. org/10.4067/S0034-98872013001100013. Cited 2017 December 30.

19. Instituto Nacional de Estadística e Informática. Sistema de documentación virtual de investigaciones estadísticas. Lima: INEI; 2017. Available from: http://webinei.inei.gob.pe/anda_inei/index.php /catalog/195. Cited 2017 December 30.

20. Instituto Nacional de Estadística e Informática. Metodología para la medición de la pobreza. Lima: INEI; 2000. (Colección Metodologías Estadísticas.) Available from: https://www.inei.gob.pe /media/MenuRecursivo/metodologias/pobreza01.pdf. Cited 2017 December 30.

21. Gujarati D. Econometría, 5th ed. Bogotá: Mc Graw Hill; 2010:318.

22. Cameron A, Trivedi P. Microeconometrics: Methods and Applications. Cambridge: Cambridge University Press; 2005:80-1.

23. International Monetary Fund. World Economic Outlook Database. Washington, DC: IMF; 2016.

24. Defensoría del Pueblo. Camino al Aseguramiento Universal en Salud (AUS). Resultados de la supervisión nacional a hospitales. Informe Defensorial No. 161. Lima: Defensoría del Pueblo; 2013. Available from: http://www2.congreso.gob.pe/sicr/cendocbib /con4_uibd.nsf/9D2A7AFD45EA318905257BCE0078F1E7/\$FILE /2.informe-161.pdf. Cited 2017 December 30.

25. Ministerio de Economía y Finanzas. Portal de Transparencia Económica, Consulta Amigable. Lima: Ministerio de Economía y Finanzas. Available from: http://www.minsa.gob.pe/portal /Comisiones/Transferencia/plan.asp. Cited 2017 December 30.

Manuscript received on 21 September 2017. Accepted for publication, after review, on 11 December 2017. 


\section{Determinantes del gasto de bolsillo en salud de la población pobre atendida en servicios de salud públicos en Perú, 2010-2014}

RESUMEN Objetivo. El objetivo de este estudio fue averiguar qué factores afectan el gasto de bolsillo en servicios de salud prestados por el MINSA y los gobiernos regionales a la población en condiciones de pobreza monetaria relativa entre 2010 y 2014.

Materiales y métodos. Estudio transversal descriptivo econométrico con cortes anuales (2010-2014) a nivel nacional con información de encuestas de hogares. La variable dependiente fue el gasto de bolsillo en salud de las personas en situación de pobreza monetaria relativa para costear su atención médica en servicios de salud públicos. Las variables independientes fueron la afiliación al Seguro Integral de Salud (SIS), el nivel de gasto familiar per capita, el grupo de edad (0-5 años), ser mujer en edad fértil (15-49 años), ser persona adulta mayor (mayor de 60 años)), la carga familiar (cuyo indicador proxy fue el número de miembros en el hogar), y el nivel de complejidad del prestador de servicios.

Resultados. Sólo 5\% de la población rural objeto de estudio fue atendida en centros de mayor nivel de complejidad (hospital) frente a $16 \%$ de la del medio urbano. Los medicamentos concentraron el mayor gasto de hogares: 44\% en los asegurados en el SIS y 62\% en los no asegurados (2014). El gasto de bolsillo en salud se asoció positivamente con no estar afiliado en el SIS, el mayor nivel de complejidad del prestador, el nivel del gasto familiar per capita y ser adulto mayor.

Conclusiones. La afiliación al SIS es una variable de política relevante para disminuir el gasto de bolsillo en hogares pobres. El menor gasto de bolsillo de la población rural pobre, especialmente vulnerable, está fuertemente asociado con el uso casi exclusivo de servicios provistos por prestadores del primer nivel de atención. Se necesitan políticas específicas de protección de la población adulta mayor en condiciones de pobreza. Para lograr la cobertura universal en salud, Perú necesita políticas más intensivas de protección financiera y de reestructuración de su oferta pública.

Palabras clave Seguro de salud; pobreza; gasto de bolsillo; cobertura universal; Perú.

\section{Determinantes da despesa por conta própria em saúde da população pobre atendida em serviços públicos de saúde, Peru, 2010-2014}

RESUMO

Objetivo. Examinar os fatores que influem na despesa por conta própria em serviços de saúde prestados pelos governos federal (Ministério da Saúde) e regionais à população em situação de relativa pobreza entre 2010 e 2014.

Materiais e métodos. Estudo transversal descritivo econométrico com recortes anuais (2010-2014) realizado em nível nacional com dados de pesquisas domiciliares. A variável dependente foi despesa por conta própria em saúde de pessoas em situação de relativa pobreza para custear o atendimento médico em serviços públicos de saúde. As variáveis independentes foram ser segurado do Seguro Integral de Saúde (SIS) da rede pública, despesa familiar per capita, faixa etária (0-5 anos), ser mulher em idade reprodutiva (15-49 anos), ser idoso (acima de 60 anos), carga familiar (cujo indicador substituto foi o número de pessoas por domicílio) e nível de complexidade do prestador de serviços.

Resultados. Apenas 5\% da população rural estudada foram atendidos em centros com nível de complexidade mais alto (hospitais) em comparação a 16\% da população urbana. Os medicamentos representaram o maior gasto das famílias: 44\% para os segurados do SIS e 62\% para não segurados (2014). A despesa por conta própria em saúde foi positivamente associada a não ser segurado do SIS, nível de complexidade mais alto do prestador de serviços, nível de gasto familiar per capita e ser idoso.

Conclusões. Ser segurado do SIS é uma variável de política importante para reduzir a despesa por conta própria em famílias pobres. A menor despesa por conta própria na população rural pobre, particularmente vulnerável, está muito associada ao uso quase exclusivo de serviços de atenção primária. Fazem-se necessárias políticas específicas de proteção da população idosa vivendo em situação de pobreza. Para alcançar a cobertura universal de saúde, o Peru precisa de políticas mais firmes de proteção financeira e reestruturação da oferta pública.

Palavras-chave Seguro Saúde; pobreza; despesas do próprio bolso; cobertura universal; Peru 